\begin{tabular}{|c|c|}
\hline (a) & 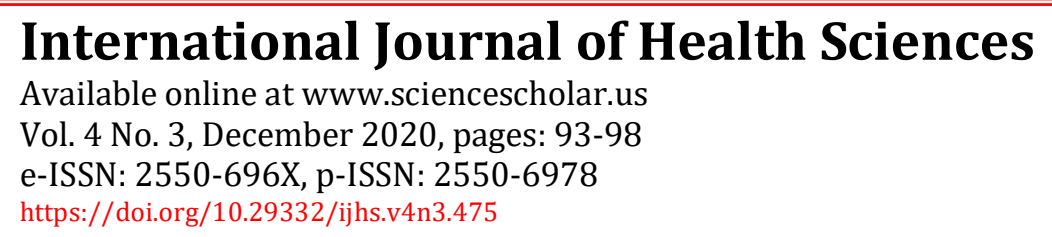 \\
\hline
\end{tabular}

\title{
Effectiveness Combination Breast Care of with Lavender Aromatherapy Towards Breast Milk Production in Postpartum Women
}

Serly Monika br Sembiring a

Manuscript submitted: 27 September 2020, Manuscript revised: 09 October 2020, Accepted for publication: 18 November 2020

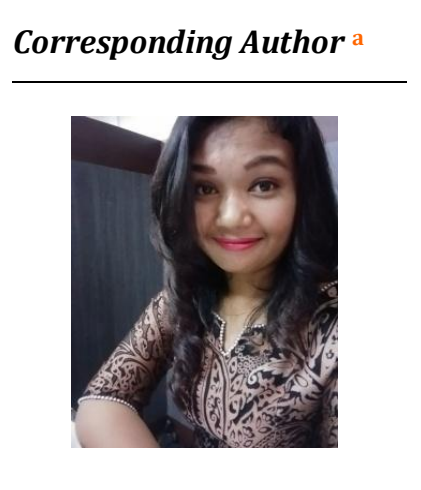

Keywords

breast care; breast milk production; lavender aromatherapy; mother inadequacy postpartum mother;

\begin{abstract}
Mother Inadequacy of production stopping breastfeeding early, the mother feels that she does not have sufficient milk production to meet the needs of the baby and supports adequate baby weight gain due to inadequate milk production. This research was conducted using a quasi-experimental research design with a non-randomized posttest design without a control group design. The sample in this study was postpartum mothers for less than 40 days who breastfeed with a total sample of 30 people, divided into the case group of 15 respondents and in the control group as many as 15 respondents. Data collection was carried out by giving treatment, namely a combination of breast care with lavender aromatherapy, and observing milk production after treatment. Data analysis using independent sample T-test analysis. Based on the results of the treatment group, it was obtained an average value of 16.2 and an average value of the Control group of 12.4, the two groups had an average difference of 3.7 with a Sig value of 0.022 less than 0.05 . It can be stated that there is a significant difference in milk production between the intervention and control groups.
\end{abstract}

International Journal of Health Sciences (C) 2020. This is an open access article under the CC BY-NC-ND license (https://creativecommons.org/licenses/by-nc-nd/4.0/).

\section{Contents}

Abstract

1 Introduction

4

4

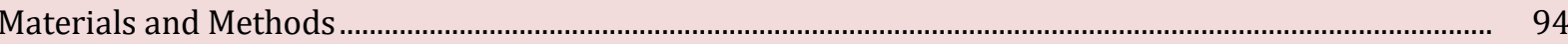

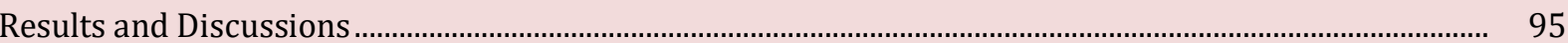

Conclusion

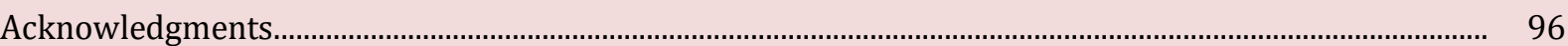

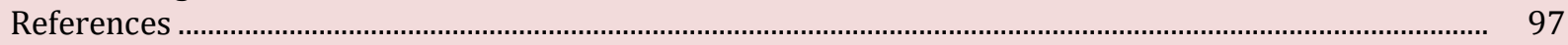

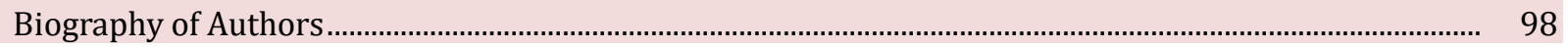

${ }^{\text {a }}$ Undergraduate Program in Midwifery, North Sumatra Health Institute, Medan, Indonesia 


\section{Introduction}

The puerperium or puerperium period is the period after childbirth is finished and ends after about 6 weeks. The term puerperium comes from the word puer which means child. Perele means giving birth shows a 6 week period that lasts between the end of the labor period and the return of the female reproductive organs to their normal condition (Anggraini, 2010).

The mother's factor that becomes a problem in breastfeeding is milk production. Breast milk production problems on the first day after delivery can be caused by reduced stimulation of the hormone oxytocin. Psychological factors are things that need attention. After giving birth, the mother experiences physical and physiological changes that result in psychological changes. This condition can affect lactation.

A mother often experiences problems in exclusive breastfeeding, one of the main obstacles is the production of breast milk that is not smooth. This will be a factor in the low coverage of exclusive breastfeeding for newborns (Wulandari, 2011). Based on the 2017 Indonesian Health Profile, babies who received exclusive breastfeeding were $35.73 \%$. In Indonesia, North Sumatra Province ranks the lowest in exclusive breastfeeding, which is $10.73 \%$.

Factors that influence the production of breast milk include breast care. Breast care (breast care) is an activity that is done consciously and regularly to maintain breast health. Breast care is very important for mothers because it is an act of care performed by patients or assisted by other people, usually starting from the first or second day after giving birth (Rosanah, 2015; Drewnowski et al., 2000; Damman et al., 2009).

The purpose of breast care (breast care) is to improve blood circulation and prevent blockage of the milk ducts so that milk is released smoothly. Breast milk production and breastfeeding production are influenced by two hormones, namely prolactin, and oxytocin. Prolactin affects the amount of breast milk production, while oxytocin affects the process of expressing breast milk (Maritalia, 2012; Latifah et al., 2015).

Mothers who experience physical and emotional stress can interfere with the reflex of breastfeeding and the hormone oxytocin. The adrenal hypothalamus-pituitary regulates stress adaptation by producing the hormones cortisol and endorphins. If cortisol levels increase, it will affect breast milk production (Jamilah et al., 2013; Kent et al., 2012; Ogawa et al., 2004). Lavender aromatherapy is also effective in reducing anxiety and stress in postpartum mothers in Iran, and also for preventing the occurrence of postpartum depression / postpartum blues which can interfere with the interests of mothers, babies, and family members (Kianpour et al., 2016).

\section{Materials and Methods}

The research was carried out at the Midwives Practice Mandiri, Medan Tuntung District. North Sumatra Province. This type of research used a quasi-experimental research design with a non-randomized posttest design without a control group design. The population in this study were all postpartum mothers for less than 40 days who breastfed at each Independent Practice Midwife (Groer \& Morgan, 2007; Imura et al., 2006). Sampling in this study using accidental sampling technique 50\% of the total population (Notoatmodjo, 2010), then obtained a total sample of 30 people. The number of samples in the case group was 15 respondents and in the control group were 15 respondents. To determine whether or not the sample is appropriate to represent the entire population, inclusion criteria are made, namely: willingness to be a respondent, mothers who give birth to live and single babies, mothers who are breastfeeding, postpartum mothers $<40$ days, mothers who do not normally receive breast care, and mothers who do not consume breast milk streamers (Mulyani, 2018). The data used in this study are primary, namely data taken directly from respondents (postpartum mothers) at the Independent Practice Midwives (BPM). Data analysis using independent sample T-test analysis. 


\section{Results and Discussions}

\section{Variable descriptive test}

Based on the results of the descriptive analysis above, the $\mathrm{N}$ value is 15 , which means that the number of respondents tested in each group is 15 as many as respondents. In the treatment group, the minimum value of 11 indicates the lowest amount of breast milk production in 7 days of testing is $11 \mathrm{cc}$. The maximum value of 25.29 shows the highest amount of breast milk production in 7 days of testing is 25.29 cc. The mean value of 16.2487 shows that the average amount of breast milk production in the 7 days of testing is $16.2487 \mathrm{cc}$ with a standard deviation of 3.90578 .

In the control group or without treatment, the minimum value of 5.86 shows the lowest amount of breast milk production in 7 days of testing is $5.86 \mathrm{cc}$. The maximum value of 22.00 indicates the highest amount of breast milk production in 7 days of testing is $22.00 \mathrm{cc}$. The mean value of 12.4760 shows that the average amount of breast milk production in the 7 days of testing is $12.4760 \mathrm{cc}$ with a standard deviation of 4.58222 . Can be seen in table 1 below:

Table 1

Descriptive test of variables

\begin{tabular}{llllll}
\hline & N & Minimum & Maximum & Mean & Std. Deviation \\
\hline Treatment Group & 15 & 11.00 & 25.29 & 16.2487 & 3.90578 \\
Control Group & 15 & 5.86 & 22.00 & 12.4760 & 4.58222 \\
Valid N (listwise) & 15 & & & & \\
\hline
\end{tabular}

\section{Normality}

Test Normality test is used to determine whether the data is normally distributed or not, the test used in this study uses the normality test method with the test Shapiro-. It is because the sample is less than 50 . The basis for decision making in the normality test is: if the significance value is greater than 0.05 , the data is normally distributed. Conversely, if the significance value is smaller than 0.05 , the data is not normally distributed.

Table 2

Normality test

\begin{tabular}{|c|c|c|c|c|c|c|}
\hline & \multicolumn{3}{|c|}{ Kolmogorov-Smirnova } & \multicolumn{3}{|c|}{ Shapiro-Wilk } \\
\hline & Statistic & $\mathrm{df}$ & Sig. & Statistics & $\mathrm{df}$ & Sig. \\
\hline Treatment groups & .189 .938 .355 & 15 & & & 15 & .183 \\
\hline Control group & .200 .939 .374 & 15 & * & & 15 & .137 \\
\hline
\end{tabular}

*. This is a lower bound of the true significance.

a. Lilliefors Significance Correction

Based on the output above, it is known that the value of Asymp. Sig. (2-tailed) Shapiro-Wilk data in the Treatment Group of 0.355 and the Control Group of 0.374 have a value greater than 0.05 , so it can be concluded that the data in this study are normally distributed.

\section{Research data}

Analysis of research data based on the results of the test table Independent Sample T-Test in the intervention group with the control group can be seen in table 3 following:

Sembiring, S. M. br . (2020). Effectiveness combination breast care of with lavender aromatherapy towards breast milk production in postpartum women. International Journal of Health Sciences, 4(3), 93-98. https://doi.org/10.29332/ijhs.v4n3.475 
Table 3

Independent Sample T-test

\begin{tabular}{lcccc}
\hline \multicolumn{1}{c}{ Group } & Average & $\begin{array}{c}\text { Difference in } \\
\text { Average }\end{array}$ & Sig Value & Information \\
\hline $\begin{array}{l}\text { Treatment } \\
\text { Control }\end{array}$ & 16.2487 & 3.77267 & 0.022 & $\begin{array}{l}\text { Significant } \\
\text { Difference }\end{array}$ \\
\hline
\end{tabular}

Based on the test results of the Independent Sample T-Test table test in the Treatment Group obtained values The average value of 16.2487 and the average value of the Control Group (Without Treatment) of 12.4760, the two groups have an average difference of 3.77267 with a Sig value of 0.022 less than 0.05 , it can be stated that there is a significant difference in milk production between the group of mothers who received treatment and the group of mothers who did not receive treatment (Control Group). Can be seen in Table 3. The following:

Problems from mothers that arise during breastfeeding can begin before delivery (antenatal period), in the early postpartum period, and the late postpartum period. Problems in infants are generally related to lactation management, so babies often become "confused about the nipple" or cry a lot, which is often interpreted by mothers and their families that breast milk is not right for the baby. Breast care is an act of sequencing or providing regular stimulation of the breast muscles to improve blood circulation, caring for the nipples to keep them clean and not prone to blisters, and to facilitate the production of MILK. Based on Rahayuningsih et al. (2016), published in the Journal of Maternal and Child Health, it is proven that there is a positive effect of breast care and oxytocin massage on the production of breast milk (ASI). Maintenance of the breast (breast care) postnatal started as early as possible, ie 1-2 days after the baby is born, and carried out 2 times a day (Astuti et al., 2015). In the first days of the baby's birth, if the nipple suction is adequate, 10-100ml of breast milk will be gradually produced. Breast milk production will be optimal after 10-14 days of the baby's age. Healthy babies will consume $700-800 \mathrm{ml}$ per day. Breast milk production begins to decrease $500-$ $700 \mathrm{ml}$ after the first 6 months, $400-600$ at the second 6 months of the baby's age and will be $300-500 \mathrm{ml}$ by the second year of the child's age.

Wahida et al. (2016), showed that back massage treatment using lavender was 3.33 times the risk of increasing breast milk production. Sukmaningrum et al. (2017), stated that from the results of the study, it was found that there was an effect of the frequency of breast care on the smoothness of breastfeeding in mother's post-section caesarian in the Rahma Room of PKU Muhammadiyah Gombong Hospital. Research conducted by Koulivand et al. (2013), stated that inhaling lavender aromatherapy can have a relaxing effect on the central nervous system. The hypothalamus in the central nervous system functions to produce the hormone oxytocin. So that the relaxing effect on the central nervous system helps increase the production of the hormone oxytocin which has an impact on increasing breast milk production.

\section{Conclusion}

Based on the results of this study, there is a significant difference in breast milk production between the group of mothers who received treatment and the group of mothers who did not get treatment (the control group).

\section{Acknowledgments}

The authors thank the Directorate of Research and Community Service, Directorate General of Research Strengthening and Development of the Ministry of Research, Technology and Higher Education (Kemenristek Dikti), which has provided research grants for Beginner Lecturer Research 2020. 


\section{References}

Anggraini, Y. (2010). Asuhan kebidanan masa nifas.

Astuti, S., Judistiani, T.D., Rahmiati, L., Susanti, A.I. (2015). Postpartum \& Breastfeeding Midwifery Care. Erlangga: Jakarta.

Damman, O. C., Hendriks, M., \& Sixma, H. J. (2009). Towards more patient centred healthcare: A new Consumer Quality Index instrument to assess patients' experiences with breast care.European Journal of Cancer, 45(9), 1569-1577. https://doi.org/10.1016/j.ejca.2008.12.011

Drewnowski, A., Henderson, S. A., Hann, C. S., Berg, W. A., \& T RUFFIN, M. A. C. K. (2000). Genetic taste markers and preferences for vegetables and fruit of female breast care patients. Journal of the American Dietetic Association, 100(2), 191-197. https://doi.org/10.1016/S0002-8223(00)00061-4

Groer, M. W., \& Morgan, K. (2007). Immune, health and endocrine characteristics of depressed postpartum mothers. Psychoneuroendocrinology, 32(2), 133-139. https://doi.org/10.1016/j.psyneuen.2006.11.007

Imura, M., Misao, H., \& Ushijima, H. (2006). The psychological effects of aromatherapy-massage in healthy postpartum mothers. Journal of midwifery \& women's health,51(2), e21-e27. https://doi.org/10.1016/j.jmwh.2005.08.009

Jamilah, B., Hartina, M. U., Hashim, D. M., \& Sazili, A. Q. (2013). Properties of collagen from barramundi (Lates calcarifer) skin. International Food Research Journal, 20(2).

Kent, J. C., Prime, D. K., \& Garbin, C. P. (2012). Principles for maintaining or increasing breast milk production.Journal of Obstetric, Gynecologic \& Neonatal Nursing, 41(1), 114-121. https://doi.org/10.1111/j.1552-6909.2011.01313.x

Kianpour, M., Mansouri, A., Mehrabi, T., \& Asghari, G. (2016). Effect of lavender scent inhalation on prevention of stress, anxiety and depression in the postpartum period. Iranian journal of nursing and midwifery research, 21(2), 197.

Koulivand, P. H., Khaleghi Ghadiri, M., \& Gorji, A. (2013). Lavender and the nervous system. Evidence-Based Complementary and Alternative Medicine, 2013.

Latifah, J., Wahid, A., \& Agianto, A. (2015). Perbandingan Breast Care dan Pijat Oksitosin terhadap Produksi ASI pada Ibu Post Partum Normal. Dunia Keperawatan: Jurnal Keperawatan dan Kesehatan, 3(1), 34-43.

Maritalia, D. (2012). Postpartum \& Breastfeeding Midwifery Care. Nuha Medika: Yogyakarta.

Mulyani, S. (2018). Work and knowledge of mother readiness in exclusive breastfeeding. International research journal of management, IT and social sciences, 5(4), 91-97.

Notoatmodjo, S. (2010). Metodologi penelitian kesehatan.

Ogawa, J., Sasahara, A., Yoshida, T., Sira, M. M., Futatani, T., Kanegane, H., \& Miyawaki, T. (2004). Role of transforming growth factor- $\beta$ in breast milk for initiation of IgA production in newborn infants. Early human development, 77(1-2), 67-75. https://doi.org/10.1016/j.earlhumdev.2004.01.005

Rahayuningsih, T., Mudigdo, A., \& Murti, B. (2016). Effect of Breast Care and Oxytocin Massage on Breast Milk Production: A study in Sukoharjo Provincial Hospital. Journal of Maternal and Child Health, 1(2), 101-109.

Rosanah, H. M. (2015). Ibadah Penuh Berkah Ketika Haid \& Nifas. Lembar Langit Indonesia: Jakarta.

Sukmaningrum, H., Eka, R., Podo, Y. (2017). The Effect of Frequency on the Breast Care Smoothness of Breastfeeding in Post Sectio Caesaria Mothers in the Rahma Room at PKU Muhammadiyah Gombong Hospital.

Wahida, J., Hakimi, M., Isnaeni, Y. (2016). The Effectiveness of Back Massage Using Lavender Essential Oil on Post-Copy Mother's Milk Production. Journal of Nursing and Midwifery, Vol 12, June 1, 2016.

Wulandari, H. (2011). Postpartum Maternity Care. Yogyakarta: Gosyen Publishing.

Sembiring, S. M. br. (2020). Effectiveness combination breast care of with lavender aromatherapy towards breast milk production in postpartum women. International Journal of Health Sciences, 4(3), 93-98. https://doi.org/10.29332/ijhs.v4n3.475 


\section{Biography of Authors}

\begin{tabular}{|l|l|l|}
\hline & $\begin{array}{l}\text { Serly Monika br Sembiring Born in Kabanjahe, May 25, 1987. Graduates of D-III } \\
\text { Midwifery ARTA Kabanjahe (2008), D-IV Midwifery Educator Poltekkes Ministry } \\
\text { of Health Medan (2010) and USU's Masters in Public Health (2013). Currently, he } \\
\text { is a teaching staff at the North Sumatra Health Institute. } \\
\text { Email: serlykembaren25@gmail.com }\end{array}$ \\
\hline
\end{tabular}

